
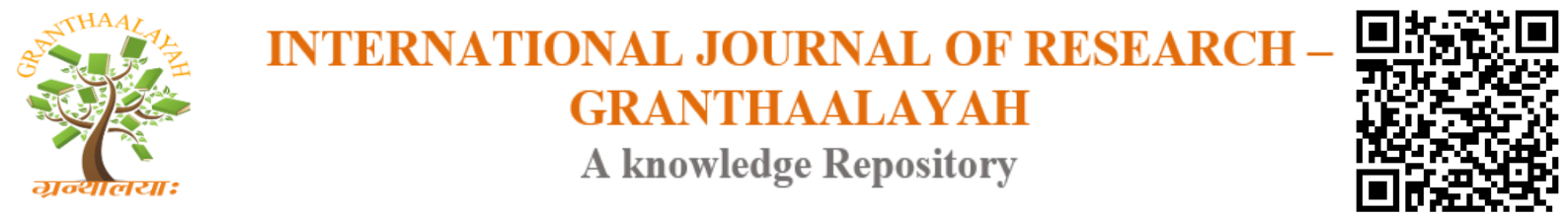

Science

\title{
DRYING EFFECTS ON ULTRASONIC ASSISTED PHENOLIC YIELDS AND RETENTIVENESS OF ANTIRADICAL PROPERTIES OF COMMON CULINARY SPICES GINGER (ZINGIBER OFFICINALE) AND TURMERIC (CURCUMA LONGO): HPTLC AND GC - MS PROFILE FOR THEIR ACTIVE INGREDIENTS ASSESSMENT
}

\author{
Nagarajan Leebanon Poonkuil ${ }^{1}$, J. Dhaveethu Raja ${ }^{2}$ \\ ${ }^{1}$ Department of Chemistry, Manonmaniam Sundaranar University, Tirunelveli, 627062 Tamil \\ Nadu, India \\ ${ }^{2}$ Chemistry Research Centre, Mohamed Sathak Engineering College, Kilakarai, 623806 Tamil \\ Nadu, India
}

\begin{abstract}
The effect of drying on antiradical activity of Zingiber officinale (ginger) and Curcuma longo (turmeric) were studied by total phenolic content (TPC), total reducing power (TRP), 2,2'-azinobis(3-ethyl benz thiazoline-6-sulphonicacid) (ABTS), 2,2-Diphenyl-1-picrylhydrazyl (DPPH) and superoxide radical scavenging assays. Comparing fresh and dried rhizome, optimum antiradical activity was observed in dry ginger and in fresh turmeric. The drying phenomenon diminished the scavenging capacity especially in turmeric and also ginger rhizome was exhibited highest superoxide radical scavenging solely at fresh state. The extraction parameters were standardized for maximum recovery of phenolics. The Zingiberene of ginger and curcumin of turmeric rummaged the free radicals energetically.
\end{abstract}

Keywords: Ginger; Turmeric; Phenolics; Drying; Antiradical Activity.

Cite This Article: Nagarajan Leebanon Poonkuil, and J. Dhaveethu Raja. (2017). "DRYING EFFECTS ON ULTRASONIC ASSISTED PHENOLIC YIELDS AND RETENTIVENESS OF ANTIRADICAL PROPERTIES OF COMMON CULINARY SPICES GINGER (ZINGIBER OFFICINALE) AND TURMERIC (CURCUMA LONGO): HPTLC AND GC - MS PROFILE FOR THEIR ACTIVE INGREDIENTS ASSESSMENT." International Journal of Research Granthaalayah, 5(9:SE), 7-23. https://doi.org/10.5281/zenodo.1004499.

\section{Introduction}

The culinary spices are the rich sources of phenolic compounds [1] which exhibiting antiradical properties [2]. Ginger and turmeric spices are having an effect on the nature, colour and taste of foods and are practiced as a medicine for dermatologic diseases, infection, stress and depression [3] in India and China since old folk times [4] due to the presence of phenolics [5]. They grow from an aromatic tuber like underground stem. Ginger are recorded over 12 antiradical 
constituents, which neutralising free radicals and reduce the inflammation these combined actions are more dominant than vitamin $\mathrm{C}$ [6]. Turmeric's orange - yellow coloured poly phenol curcuminoids which composed of Curcumin (C), Demethoxy curcumin (DMC) and Bisdemethoxy curcumin (BDMC) [7] also known recently for antiradical [8] anti - inflammatory, anti - cancer effects [9] and reported for neurological, autoimmune, cardiovascular disorders [10]. The sum of free radical activity of a given food based phenolics were stationed on the additory effects of enzymatic and chemical processes that arose in the course of drying, processing and storage [11,12]. Now a days, after the harvesting, leaves of ginger and turmeric are dried and wasted which can be better exploited for the extraction of antiradicals that are much desired in the wellness program plus food processing industries and also can be utilized effectively for replacing the synthetic antiradical compounds and preservatives. The present study aims the effect of drying on phenol extracts for making natural antiradical agents.

\section{Materials and Methods}

\subsection{Plant Materials}

The fresh rhizomes, leaves and fresh roots of ginger and turmeric were collected from the land of Kamatchipuram, Theni district, Tamilnadu, India during July 2017. A part of plant materials were washed, cut in to small pieces $(2-10 \mathrm{~g})$ and ground with a blender to make powder. A part of samples were dried overnight in a tray in Regional research laboratory Trivandrum natural Convection (RRL T - NC) dryer at $40^{\circ} \mathrm{C}$. It was ground well to make powder.

\subsection{Ultrasonic Assisted Extraction of Phenolics}

$50 \mathrm{~mL}$ of $70 \%$ ethanol, $70 \%$ methanol, $70 \%$ acetone and distilled water were added to the samples and were sonicated for 30 minutes (mins) thence centrifuged, filtered and concentrated in a rotary evaporator at below $50^{\circ} \mathrm{C}$ under reduced pressure at varying sonication frequencies $(20,40,60,80,100$ and $120 \mathrm{Hertz}[\mathrm{Hz}])$ by keeping time constant and vice versa. The yield and the TPC were determined and read in Ultra violet (UV) visible spectrophotometer at $760 \mathrm{~nm}$ [13].

\subsection{TPC}

Appropriately diluted extracts and standard gallic acid were made up to $3.5 \mathrm{~mL}$ and treated with $0.5 \mathrm{~mL} 2 \mathrm{~N}$ Folin - ciocalteu's reagent and set for 3 mins in room temperature [14]. The reaction mixture was then neutralised with the addition of $1 \mathrm{~mL} 20 \% \quad \mathrm{Na}_{2} \mathrm{CO}_{3}$ and kept at room temperature for 90 mins and the absorbance of the blue colour was absorbed at $760 \mathrm{~nm}$ which expressed as [15];

(observed concentration / actual concentration) x $100=\% \mathrm{TPC}$

\subsection{TRP}

The different concentrations of extracts and standard $(10,20,40,60,80$ and $100 \mu \mathrm{g} / \mathrm{mL}$ for ginger) $(80,160,240,320$ and $400 \mu \mathrm{g} / \mathrm{mL}$ for turmeric) in $1 \mathrm{~mL}$ of distilled water were stirred with phosphate buffer $(2.5 \mathrm{~mL}, 0.2 \mathrm{M}, \mathrm{pH} 6.6)$ and potassium ferricyanide $\left[\mathrm{K}_{3} \mathrm{Fe}(\mathrm{CN})_{6}\right](2.5 \mathrm{~mL}$, 
$1 \% \mathrm{w} / \mathrm{v})$ and incubated for $20 \mathrm{mins}$ at $50^{\circ} \mathrm{C}$. Then $2.5 \mathrm{~mL}$ of trichloro acetic acid $(10 \% \mathrm{w} / \mathrm{v})$ was added to the mixture, which was then centrifuged for at $1000 \mathrm{~g}$ for $10 \mathrm{mins}$. The upper layer of solution $(2.5 \mathrm{~mL})$ was mixed with distilled water $(2.5 \mathrm{~mL})$ and $\mathrm{FeCl}_{3}(0.5 \mathrm{~mL}, 0.1 \% \mathrm{w} / \mathrm{v})$ and the absorbance was evaluated at $700 \mathrm{~nm}[16]$.

\subsection{DPPH radical scavenging capacity}

$1 \mathrm{~mL}$ of $0.3 \mathrm{mM}$ DPPH ethanol solution was added to $2.5 \mathrm{~mL}$ of sample solutions at different concentrations and permitted to act in room temperature. The absorbance was determined at 518 $\mathrm{nm}[17]$.

$$
A_{c}-A_{s} / A_{c} \times 100=\% \operatorname{RSA}
$$

where $\mathrm{A}_{\mathrm{c}}$, absorbance of control; $\mathrm{A}_{\mathrm{s}}$, is the absorbance of sample; RSA, Radical scavenging activity. The $\%$ of RSA was plotted against the corresponding concentration of the extracts to obtain the half maximal inhibitory concentration

$\left(\mathrm{IC}_{50}\right)$ value which was defined as the amount of antiradical material required to scavenge $50 \%$ of free radical in the assay system. These values are inversely proportional to the antiradical activity [18].

\subsection{ABTS Radical Scavenging Capacity}

$7 \mathrm{mM}$ stock solution of ABTS was mixed with $2.45 \mathrm{mM}$ potassium per sulphate and allowed the mixture to stand in the dark for at least 6 hours in room temperature. The ABTS solution was diluted to the absorbance of $0.7 \pm 0.05$ at $736 \mathrm{~nm}$. The absorbance was measured 7 mins after the initial mixing of different concentrations of the extracts [19]. The $\mathrm{ABTS}^{+}$decolourizing capacity of the extracts were compared with the standard trolox. A standard curve was prepared by measuring the reduction in the absorbance of $\mathrm{ABTS}^{+}$solution at different concentrations of trolox over a period of 7 mins [20]. The antiradical capacities were determined as follow;

$$
\mathrm{A}_{\mathrm{c}}-\mathrm{A}_{\mathrm{s}} / \mathrm{A}_{\mathrm{c}} \times 100=\% \mathrm{RSA}
$$

\subsection{Superoxide Radical Scavenging Activity}

The Superoxide anion was generated in $3 \mathrm{~mL}$ of tris - $\mathrm{HCl}$ buffer $(100 \mathrm{mM}$, pH 7.4) contained $0.75 \mathrm{~mL}$ of phenazine methosulphate (PMS) $(120 \mu \mathrm{M})$ was added to the sample mixture and then incubated for $5 \mathrm{mins}$ in room temperature. Read at $560 \mathrm{~nm} \mathrm{[21]} \mathrm{and} \mathrm{calculated} \mathrm{as} \mathrm{follows} \mathrm{[22];}$

$$
\left(\mathrm{A}_{0}-\mathrm{A}_{1}\right) / \mathrm{A}_{0} \times 100=\% \text { Inhibition }
$$

where $\mathrm{A}_{0}$, absorbance of the control; $\mathrm{A}_{1}$, absorbance of the extract

\subsection{Determination of Volatile Ginger Oil by Gas Chromatography - Mass Spectrometry (GC - MS) Analysis}

$100 \mathrm{~g}$ of ginger sample was heated with frequent agitation until evolution commenced and continued the distillation at the rate of 60 - 75 drops / mins. Distilled for not less than 4 hours and at the end of the period, discontinued the heating. Read off the volume of oil and continued 
the distillation until two consecutive readings were marked at 1 hour interval showed no changes in the volume collected in the graduated portion and estimated using Clevenger trap apparatus.

$\mathrm{a} / \mathrm{b} \times 100=$ Essential oil content $[\mathrm{v} / \mathrm{w}]$.

where, $a=$ volume of oil, $b=$ weight of the sample [23].

\subsection{Gas Liquid Chromatography (GLC) Analysis of Spice Samples}

The percentage of different quantities of each chemical constituent in ginger oil could be obtained from GLC [24]. Set the condition of GLC and injected the samples. The chromatogram showed as peaks in the recorder with definite retention time under specified conditions [25].

\subsection{Determination of Active Constituents of Turmeric by High Performance Thin Layer Chromatography (HPTLC)}

The processed turmeric powder $(1 \mathrm{~g})$ was ultrasonically extracted with aqueous methanol for 15 mins and filtered. The extract was concentrated under reduced pressure in $1 \mathrm{~mL}$ of methanol [26]. $4 \mu \mathrm{L}$ was carried off and known concentrations of standards were applied to the pre - silica gel HPTLC plate and they were pre - saturated with the mobile phase chloroform-methanol for 30 mins, the length of each run was $7 \mathrm{~cm}$. Then the plates were dried in air. For quantification, the TLC spot corresponding to the samples and standards were quantified at $425 \mathrm{~nm}$ using a Camag TLC scanner model - 3 equipped with Camag win cats software and a tungsten source [27]. Curcuminoids in the samples were automatically interpolated from the calibration curve. The peak corresponding to the curcuminoids were checked via addition of standard and elucidated for identification [28].

\section{Results and Discussion}

The antiradical activity of various parts of ginger and turmeric were studied by different assay methods such as TPC, TRP, DPPH, ABTS, and superoxide radical scavenging activity. The solvent system, sonication frequency and contact time parameters were optimized and standardised to obtain maximum TPC.

\subsection{Optimization of Solvent System}

The topmost yields were discovered for fresh and dried rhizome of ginger with $70 \%$ methanol $(2.4 \% \& 3.7 \%)$ and for fresh leaves and root with $70 \%$ acetone $(5 \% \& 5.5 \%)$ (Table 1). It was noted that on drying the TPC content of ginger was reduced due to the reduction of phenolic hydroxyls [29] and underwent structural changes since their enzymes were lost. Prieto and co workers were observed that fresh ginger roots were contained ample range of phenolics [30] which could be large enough for several activities. Overall the high values were noted with acetone extract of dried turmeric rhizome (19.42\%) (Table 2). The optimum extraction was obtained with methanol (fresh and dried ginger rhizome) and acetone (fresh ginger, turmeric leaves and ginger root) (Table 7). In the case of turmeric, optimal extraction was showed by ethanolic (fresh and dried rhizome) fraction (Table 8). Henceforward these solvents were chosen for further analyses. 


\subsection{Optimization of Extraction Time}

When the extraction time was 40 mins, the supreme TPC were obtained about 9.6\%, 22.7\%, $6.5 \%$ and $5.84 \%$ for fresh, dry ginger rhizome, fresh leaves and roots correlatively (Table 3). But at 80 mins incubation, the samples were disclosed less TPC, thus the contact time of 40 mins was fixed for entire samples of ginger (Table 7). The TPC of fresh turmeric was observed as high about 4.5\%, 3.8\% with 80 mins for fresh and dried rhizome consequently (Table 4). Hence the divergent periods were standardised as 80 and $60 \mathrm{mins}$ for maximal extraction of phenolics from turmeric (Table 8).

\subsection{Optimization of Sonication Power}

At $80 \mathrm{~Hz}$, fresh and dried ginger rhizomes were revealed an upgrade yield (5.2 \& 8.3\%) and elevated TPC ( $4.17 \& 9.47 \%$ ). So the optimum sonication frequency was patterned as $80 \mathrm{~Hz}$ for dry and fresh ginger rhizomes (Table 5 and 7). In the batch of fresh turmeric rhizome, optimal TPC was observed at $120 \mathrm{~Hz}$, but maximum yield of extracts with $80 \mathrm{~Hz}$. Yet in the fresh turmeric leaves paramount yield and TPC were obtained at $60 \mathrm{~Hz}$ and $80 \mathrm{~Hz}$ correspondingly (Table 6). Hence the optimum sonication frequency for fresh and dried turmeric rhizomes were fixed at 60 and for fresh turmeric leaves at $80 \mathrm{~Hz}$ (Table 8). Thus, in terms of ultra sonication time could be augmented to minimize the shrinkage for the beneficial of commercial health care industries [31].

\subsection{TPC}

On the whole, fresh ginger rhizome (11.25\% yield \& $3.09 \%$ TPC), fresh turmeric rhizome $(9.5 \%$ yield) and fresh turmeric leaves (6.91\% TPC) were exhibited groovy results but least yield $(6.25 \%)$ and poor TPC (2\%) were obtained for ginger root and dried turmeric rhizome $(4.5 \%$ yield and 4\% TPC) (Table 9 and 10). Fresh leaves are possessed a lavish availability of poly phenolic compounds and they could be decreased during storage time which might be due to the oxidation, polymerization [32] and enzymatic degradation [33,34].

\subsection{TRP}

The highest and lowest reducing powers were observed for dry ginger and ginger roots properly. The dry and fresh gingers were showcased the same TRP at $20 \mu \mathrm{g} / \mathrm{mL}$ concentration. Fresh ginger and leaves were proclaimed the same reducing power at $120 \mu \mathrm{g} / \mathrm{mL}$ due to the vast availability of volatile oil compounds, zingerone, geranial and less shogaols [35]. As the concentration was increased, dry ginger extract was streaked an upward trend while fresh ginger extract slowed down a little. The ginger root and leaves were unveiled a steady increase with the absorbance. Gallic acid $4 \mu \mathrm{g} / \mathrm{mL}$ was reciprocal to $120 \mu \mathrm{g} / \mathrm{mL}$ of dried ginger rhizome, in both the concentrations; the absorbances were comparatively equals to 0.079 . (Table S1 [supplementary material] and Graph 1). The maximum reducing power was observed in dry ginger [36]. Gallic acid is the synthetic chemical where as ginger is much better alternative.

The absorbance of turmeric extract was increased arithmetically with the concentration. Fresh leaves extract were divulged highest reducing power and flashed much higher activity compared to other extract since they contained tannins, cellulose, lignins, chlorophyll, volatile compounds 
and hemi cellulose [37]. In these assays, fresh and dry turmeric rhizomes were afforded more or less same activity. $100 \mu \mathrm{g} / \mathrm{mL}$ of fresh leaves were equivalent to $16 \mu \mathrm{g} / \mathrm{mL}$ of gallic acid (Table S2 and Graph 2). The greatest reductive potential was indicated by surpassing absorbance of the reaction mixture [38].

\subsection{DPPH Assay}

The maximum RSA was observed for dry ginger rhizome (80\%) which was followed by fresh roots $(78 \%)$ fresh rhizome $(72 \%)$ and fresh leaves $(49 \%)$ at a concentration of $100 \mu \mathrm{g} / \mathrm{mL}$ (Graph 3). Gingerols and mostly shogaols were the responsible compounds for DPPH radical scavenging, since leaves were lack of gingerols, higher $\mathrm{IC}_{50}$ was obtained. Fresh and dry gingers were expressed dissimilitude activity. DPPH scavenging results of gallic acid and ginger were prompted that $60 \mu \mathrm{g} / \mathrm{mL}$ of dry ginger was equivalent to $2 \mu \mathrm{g} / \mathrm{mL}$ of gallic acid which were showed RSA of $62.33 \%$ (Table S3). Aruoma et al., [39] were stated that the fresh leaves activities were much less and more than $100 \mu \mathrm{g} / \mathrm{mL}$ of fresh leaves are needed to socialise 5 $\mu \mathrm{g} / \mathrm{mL}$ of gallic acid. So wherever gallic acid is used as an active compound in food processing, that could be replaced by dry ginger as preservant and as an antiradical [40].

In the array of turmeric, fresh turmeric leaves were evidenced the maximum RSA of $80 \%$ even at $45 \mu \mathrm{g} / \mathrm{mL}$ and those were conserved and kept alive till $90 \mu \mathrm{g} / \mathrm{mL}$ owing to the preferable availability of tannins, enzymes and lignins which could be scavenged the radicals effectively. Whereas the RSA of fresh and dried turmeric rhizomes were hiked steady upward direction and attained the slightest $60 \%$ and $68.1 \%$ RSA indicatively (Graph 4). While those were compared with standard, all the chosen turmeric samples were projected much superior activity. Gallic acid was established only $62 \%$ RSA at $500 \mu \mathrm{g} / \mathrm{mL}$ (Table S4).

\subsection{ABTS - RSA}

The highest RSA (72.9\%) was displayed by dry ginger which was tracked by fresh ginger (70.8\%) at the concentration of $250 \mu \mathrm{g} / \mathrm{mL}$. The lowest activity was expressed by fresh leaves (64.3\%) (Graph. 5). When they were compared to gallic acid, $200 \mu \mathrm{g}$ of dry ginger and $250 \mu \mathrm{g}$ of fresh ginger were equivalent to $10 \mu \mathrm{g}$ of gallic acid. Those were flaunted the same $\%$ of RSA against ABTS (Table S5). The dry ginger was contained more shogaols while compared to fresh ginger. It was well - defined that shogaols were the better scavenger for ABTS radicals and confirmed that the dry ginger was superior to other samples.

The maximum RSA was observed for fresh turmeric rhizome at a concentration of $270 \mu \mathrm{g} / \mathrm{mL}$. The fresh turmeric leaves were resembled similar activity as fresh rhizome. The compounds namely curcuminoids, flavonoids, starch, terpenoids, glycosides and enzymes were vastly available in fresh rhizome of turmeric than dried state [13], therefore the ABTS radical scavenging activity was much higher in fresh turmeric rhizome and leaves. But the dry turmeric rhizome was disported less activity, (Graph 6) $90 \mu \mathrm{g} / \mathrm{mL}$ of dried rhizome, $60 \mu \mathrm{g} / \mathrm{mL}$ of fresh rhizome and $50 \mu \mathrm{g} / \mathrm{mL}$ of fresh turmeric extracts were equivalent to 10,8 and $4 \mu \mathrm{g} / \mathrm{mL}$ of trolox successively (Table S6). Whence in the food processing companies, the synthetic chemical [41] trolox usage could be superseded by natural turmeric extracts in future. The effects of various 
drying technologies (vacuum drying, freeze drying, hot air drying) were also influenced the antiradical capacity in great extent.[42,43,44]

\subsection{Superoxide Radical Scavenging Activity}

Fresh ginger rhizome, fresh leaves, dried ginger and fresh roots were paraded the RSA of 90.9\%, $80 \%, 73.5 \%$, and $52 \%$ at a concentration of $120 \mu \mathrm{g} / \mathrm{mL}$. Even though fresh leaves were blazoned higher RSA from $20 \mu \mathrm{g} / \mathrm{mL}$, the activity was not at all increased that much when the concentration was increased up to $120 \mu \mathrm{g} / \mathrm{mL}$ (Graph 7) but $75.83 \mu \mathrm{g} / \mathrm{mL}$ of leaves were sufficient to meet 50\% RSA. When they were compared to standard Butylated hydroxyl toluene (BHT), all the samples except ginger root were brandished the higher activity (Table S7). So it can be deduced that the fresh ginger rhizome could be functioned as a good substitute for BHT. The activity differences for dry and fresh gingers were explained on the basis of zingerone availability which was plenteous in fresh ginger and also responsible for radical scavenging activity $[45,46]$. In the unprocessed state, ginger was contained abundant zingiberene, arcurcumene, nerolidols, terpene glycosides, flavonoids and tannins [47] especially fresh ginger and fresh leaves were comprised of superoxide radical scavenging glycosidase and zingibain protease enzymes naturally, those are denatured and released terpenes and remnants by the process of drying [48].

More over $50 \%$ RSA was achieved by $90 \mu \mathrm{g} / \mathrm{mL}$ of fresh turmeric leaves, $150 \mu \mathrm{g} / \mathrm{mL}$ of fresh rhizome and $208.5 \mu \mathrm{g} / \mathrm{mL}$ of dried rhizome (Graph 8) which were loomed an increased trend from fresh turmeric leaves to dry rhizome. Both the reference compounds namely BHT and gallic acid were analysed. While those results were compared, it might be considered to the mean that $100 \mu \mathrm{g} / \mathrm{mL}$ of BHT and $50 \mu \mathrm{g} / \mathrm{mL}$ of gallic acid were equivalent to $150 \mu \mathrm{g} / \mathrm{mL}$ of fresh leaves and $210 \mu \mathrm{g} / \mathrm{mL}$ of fresh rhizome (Table S8). Following the fresh leaves, highest activity was exhibited by fresh rhizome. If the above was verbalised in another way, the drying phenomenon disturbed the compounds responsible for scavenging henceforth the fresh leaves were proffered the maximum RSA against superoxide radical when compared to fresh and dry rhizomes. Several researchers were experimentally studied the effects of drying and concluded that increases in drying temperature diminished the nutraceutical properties for instance part of gingerols were transformed into shogaols [49-52]. So the differences in activities are explained intensely. Superoxide radical was scavenged mostly by the enzymes present in the fresh ginger and fresh turmeric leaves.

\subsection{GC - MS Profile and GLC Pattern of Fresh Ginger Oil}

26 chemical constituents were found in the GC - MS essential oil of ginger. The main compound was zingiberene $(20 \%)$ which was followed by geraniol $(7.3 \%)$, beta-bisabolene $(5.5 \%)$, arcurcumene $(4 \%)$, nerol, betasesquiphellandrene, trans beta-bisabolene $(3.5 \%)$, limonene $(2.3 \%)$ (primacy fragment among the monoterpenes), beta-farnesene and cis-Nerolidol (2\%) (foremost in the class of oxygenated sesquiterpenes) (Table 11 and Figure 1).The beta- farnesene were identified better (2\%) than methanolic leaves extract of Elettaria cardamomum (cardamom) $(0.08 \%)$, the queen of spices for cooking which belongs to the same zingiberaceae family [53] The results of Aziz et al., [54] were implied that 12, 11 and 10 chemical constituents were fractioned in the GC - MS essential oil of Japan, Bangladeshi and China ginger categorically. For 
establishing the authenticity and credibility, the active ingredients quantification through GC-MS was vital [55], thus the availability of the volatile geranial and zingerone in fresh ginger rhizome were found to be responsible for the aromatic flavor [56].

\subsection{HPTLC Profile of Curcuminoids}

The curcuminoids (C, DMC and BDMC) of turmeric rhizome were screened out with regard to standard curcuminoids by HPTLC (Graph S1) which contained 3-6\% curcuminoids, 4-8\% volatile oil. The results from the crude turmeric and turmeric extracts were just homogeneous [57], and they were present in each sample retained the maximum concentration of $C$ followed by DMC and BDMC (Graph 9 [X and $\mathrm{Y}$ axis were labeled as $\mathrm{R}_{\mathrm{f}}$ and absorbance in $\mathrm{nm}$ correspondingly; $\mathrm{C} 1$, curcumin; $\mathrm{C} 2$, demethoxy curcumin; $\mathrm{C} 3$, bisdemethoxy curcumin]. and Figure 2). These outcome were coincided with the results of Ali et al., [58] who also stated that $2.1,0.46$ and $0.1 \%$ of $\mathrm{C}, \mathrm{DMC}$ and BDMC could be extracted individually. A systematic extraction could be made by demolition of turmeric cell wall through the medium of $\alpha$-amylase and amyloglucosidase enzymes to enhance the output up to 5.73\% [59] and were simultaneously identified by fast and reliable HPTLC with high purity of 96\% [60] or 85.58\% [61]. During the drying process, curcuminoids underwent structural transformation, compound dehydration, double bond migration, and oxidative polymerization. Pursuing the breakage of glycosidic linkage, novel groups were introduced in the structure after a while the different radicals would be expected. These observations are harmonised with the results of Niamnuy et al., [62] who noticed that faster drying rate kindled tremendous cellular shrinkage.

Table 1: Optimization of solvent - Yield of extraction and TPC content of ginger rhizome

\begin{tabular}{lllllllll}
\hline Solvents & \multicolumn{2}{l}{ Fresh rhizome } & \multicolumn{2}{l}{ Dried rhizome } & \multicolumn{2}{l}{ Fresh leaves } & \multicolumn{2}{l}{ Fresh root } \\
& Yield & TPC & Yield & TPC & Yield & TPC & Yield & TPC \\
& $(\%)$ & $(\%)$ & $(\%)$ & $(\%)$ & $(\%)$ & $(\%)$ & $(\%)$ & $(\%)$ \\
$70 \%$ Ethanol & 2.1 & 0.44 & 2.5 & 0.62 & 3.62 & 2.91 & 4.5 & 3.22 \\
$70 \%$ Methanol & 2.4 & 0.60 & 3.7 & 0.96 & 4.75 & 3.83 & 3.5 & 2.97 \\
70\% Acetone & 1.8 & 0.49 & 2.2 & 0.54 & 5.0 & 5.38 & 5.5 & 3.47 \\
Distilled Water & 1.5 & 0.33 & 1.4 & 0.32 & 3.25 & 2.11 & 2.0 & 1.5 \\
\hline
\end{tabular}

Extractions were performed through Ultrasound assistance $(\mathrm{Hz})$.

Table 2: Yield of extraction and TPC content of turmeric rhizome

\begin{tabular}{lllllll}
\hline \multicolumn{1}{c}{ Solvents } & \multicolumn{2}{c}{ Fresh rhizome } & \multicolumn{2}{c}{ Dried rhizome } & \multicolumn{2}{c}{ Fresh leaves } \\
& Yield & TPC & Yield $(\%)$ & TPC & Yield & TPC \\
& $(\%)$ & $(\%)$ & & $(\%)$ & $(\%)$ & $(\%)$ \\
& 13.0 & 3.84 & 19.42 & 1.38 & 7.5 & 5.024 \\
$70 \%$ Acetone & 8.0 & 3.9 & 17.20 & 2.10 & 6.0 & 2.56 \\
$70 \%$ Methanol & 7.0 & 6.0 & 18.12 & 3.28 & 6.0 & 2.67 \\
$70 \%$ Ethanol & 6.0 & 3.82 & 15.7 & 2.90 & 9.0 & 2.27 \\
Distilled Water & & & & & \\
\hline
\end{tabular}

Maximum yield of fresh turmeric leaves were gotten with aqueous extracts (9\%). 
Table 3: Optimization of time - Variation of extraction period against the yield of extraction of ginger

\begin{tabular}{lllllllll}
\hline $\begin{array}{l}\text { Time } \\
(\text { mins })\end{array}$ & \multicolumn{2}{l}{ Fresh rhizome } & \multicolumn{2}{l}{ Dried rhizome } & \multicolumn{2}{l}{ Fresh leaves } & \multicolumn{2}{c}{ Fresh root } \\
& $\begin{array}{l}\text { Yield } \\
(\%)\end{array}$ & $\begin{array}{l}\text { TPC } \\
(\%)\end{array}$ & $\begin{array}{l}\text { Yield } \\
(\%)\end{array}$ & $\begin{array}{l}\text { TPC } \\
(\%)\end{array}$ & $\begin{array}{l}\text { Yield } \\
(\%)\end{array}$ & $\begin{array}{l}\text { TPC } \\
(\%)\end{array}$ & $\begin{array}{l}\text { Yield } \\
(\%)\end{array}$ & $\begin{array}{l}\text { TPC } \\
(\%)\end{array}$ \\
& 4.2 & 5.4 & 14.2 & 21.3 & 4.1 & 3.2 & 5.5 & 4.1 \\
$40^{*}$ & 8.1 & 9.6 & 15.7 & 22.7 & 5.2 & 6.5 & 6.0 & 5.84 \\
60 & 4.2 & 5.3 & 8.2 & 12.80 & 3.1 & 4.2 & 5.25 & 3.66 \\
80 & 4.6 & 5.3 & 7.6 & 14.68 & 4.1 & 3.2 & 6.05 & 3.5 \\
100 & 3.1 & 4.9 & 6.2 & 10.40 & 3.5 & 3.9 & 4.75 & 2.27 \\
120 & 5.0 & 7.1 & 7.6 & 13.35 & 4.6 & 2.2 & 4.62 & 2.21 \\
\hline
\end{tabular}

'Yields were high at 40 mins.

Table 4: Optimization of time - Variation of extraction period against the yield of extraction of turmeric

\begin{tabular}{|c|c|c|c|c|c|c|c|c|}
\hline \multirow[t]{2}{*}{$\begin{array}{l}\text { Time } \\
\text { (mins) }\end{array}$} & \multicolumn{2}{|c|}{ Fresh rhizome } & \multicolumn{2}{|c|}{ Dried rhizome } & \multicolumn{2}{|c|}{ Fresh leaves } & \multicolumn{2}{|l|}{$\begin{array}{l}\text { Time } \\
\text { (mins) }\end{array}$} \\
\hline & $\begin{array}{l}\text { Yield } \\
(\%)\end{array}$ & $\begin{array}{l}\text { TPC } \\
(\%)\end{array}$ & $\begin{array}{l}\text { Yield } \\
(\%)\end{array}$ & $\begin{array}{l}\text { TPC } \\
(\%)\end{array}$ & $\begin{array}{l}\text { Yield } \\
(\%)\end{array}$ & $\begin{array}{l}\text { TPC } \\
(\%)\end{array}$ & $\begin{array}{l}\text { Yield } \\
(\%)\end{array}$ & $\begin{array}{l}\text { TPC } \\
(\%)\end{array}$ \\
\hline 20 & 2.5 & 3.3 & 9.8 & 1.9 & 8.0 & 10.61 & 20 & 2.5 \\
\hline 40 & 3.25 & 2.87 & 10.9 & 2.04 & 9.25 & 7.17 & 40 & 3.25 \\
\hline 60 & 4.0 & 2.49 & 13.2 & 2.21 & 5.5 & $12.29^{\star}$ & 60 & 4.0 \\
\hline 80 & 6.75 & 4.5 & 14.5 & 3.8 & 7.25 & 9.20 & 80 & 6.75 \\
\hline 100 & 1.25 & 3.8 & 15.5 & 3.0 & 9.25 & 6.59 & 100 & 1.25 \\
\hline 120 & 1.5 & 4.0 & 15.0 & 3.2 & 7.5 & 11.69 & 120 & 1.5 \\
\hline
\end{tabular}

' In the fresh turmeric leaves, $12.29 \%$ TPC was obtained with 60 mins.

Table 5: Optimization of sonication frequency - Variation of sonication frequency against the yield of extraction of ginger

\begin{tabular}{|c|c|c|c|c|c|c|c|c|}
\hline Sonication & \multicolumn{2}{|c|}{ Fresh rhizome } & \multicolumn{2}{|c|}{ Dried rhizome } & \multicolumn{2}{|c|}{ Fresh leaves } & \multicolumn{2}{|c|}{ Fresh root } \\
\hline Frequency & Yield & TPC & Yield & TPC & Yield & TPC & Yield & TPC \\
\hline$(\mathrm{Hz})$ & $(\%)$ & $(\%)$ & $(\%)$ & $(\%)$ & $(\%)$ & $(\%)$ & $(\%)$ & $(\%)$ \\
\hline 20 & 4.1 & 3.8 & 4.1 & 5.25 & 2.5 & 1.96 & 4.25 & 7.34 \\
\hline 40 & 3.9 & 3.75 & 3.2 & 4.1 & 3.7 & 2.16 & 4.25 & 4.17 \\
\hline 60 & 3.2 & 2.9 & 6.1 & 7.32 & 5.1 & 4.21 & 6.5 & 5.86 \\
\hline 80 & 5.2 & 4.17 & 8.3 & 9.37 & 4.2 & 3.51 & 6.2 & 5.68 \\
\hline 100 & 3.5 & 2.57 & 7.1 & 8.31 & $6.4^{\star}$ & $5.32^{\star}$ & 4.5 & 9.4 \\
\hline 120 & 4.2 & 3.45 & 6.2 & 8.05 & 4.2 & 3.67 & $7.25^{\star}$ & $12.72^{\star}$ \\
\hline
\end{tabular}

'Optimum frequency was $100 \mathrm{~Hz}(6.4 \%$ yield \& 5.32\% TPC) for fresh leaves and $120 \mathrm{~Hz}$ (7.25\% yield \& $12.72 \%$ TPC) for fresh root. 
Table 6: Variation of sonication frequency against the yield of extraction of turmeric

\begin{tabular}{lllllll}
\hline Sonication & \multicolumn{2}{l}{ Fresh rhizome } & \multicolumn{2}{l}{ Dried rhizome } & \multicolumn{2}{l}{ Fresh leaves } \\
Frequency & Yield & TPC & Yield & TPC & Yield & TPC \\
$(\mathrm{Hz})$ & $(\%)$ & $(\%)$ & $(\%)$ & $(\%)$ & $(\%)$ & $(\%)$ \\
20 & 1.25 & 3.8 & 9.8 & 2.3 & 6.75 & 5.65 \\
40 & 5.25 & 3.9 & 11.2 & 2.01 & 5.5 & 5.41 \\
60 & 12.0 & 4.5 & 12.0 & 1.9 & 8.25 & 3.54 \\
80 & 12.75 & 5.2 & 12.5 & 2.9 & 5.25 & 5.86 \\
100 & 11.0 & 6.7 & 14.0 & 2.92 & 6.25 & 4.01 \\
120 & 10.5 & 6.81 & 14.5 & $2.98^{\star}$ & 6.0 & 3.72 \\
\hline
\end{tabular}

- $2.98 \%$ TPC $14.5 \%$ yield at $120 \mathrm{~Hz}$ for dried rhizome.

Table 7: Standardization of parameters for optimum phenolics yield from ginger

\begin{tabular}{lllll}
\hline Samples & Solvents & $\begin{array}{l}\text { Time } \\
(\mathrm{mins})\end{array}$ & $\begin{array}{l}\text { Sonication } \\
(\mathrm{Hz})\end{array}$ & Frequency \\
Fresh rhizome & Methanol & 40 & 80 & \\
Dried rhizome & Methanol & 40 & 80 & \\
Fresh leaves & Acetone & 40 & 100 & \\
Fresh root & Acetone & 40 & 120 & \\
\hline
\end{tabular}

Table 8: Standardization of parameters for optimum phenolics yield from turmeric

\begin{tabular}{llll}
\hline Samples & Solvents & $\begin{array}{l}\text { Time } \\
(\mathrm{mins})\end{array}$ & $\begin{array}{l}\text { Sonication } \\
\text { Frequency } \\
(\mathrm{Hz})\end{array}$ \\
Fresh rhizome & Ethanol & 80 & 60 \\
Dried rhizome & Ethanol & 80 & 60 \\
Fresh leaves & Acetone & 80 & 80 \\
\hline
\end{tabular}

Table 9: TPC of optimized samples of ginger

\begin{tabular}{lll}
\hline Samples & Yield & TPC \\
& $(\%)$ & $(\%)$
\end{tabular}

Fresh rhizome $11.25^{\star} \quad 3.09^{\star}$

Dried rhizome $\quad 6.5 \quad 2.52$

Fresh leaves $\quad 10.0 \quad 2.17$
Table 10: TPC of optimized samples of turmeric

\begin{tabular}{lll}
\hline Samples & $\begin{array}{l}\text { Yield } \\
(\%)\end{array}$ & $\begin{array}{l}\text { TPC } \\
(\%)\end{array}$ \\
Fresh rhizome & $9.5^{\star}$ & 4.8 \\
Dried rhizome & 4.5 & 4.0 \\
Fresh leaves & 2.85 & $6.91^{\star}$ \\
\hline
\end{tabular}

Fresh root $\quad 6.25 \quad 2.0$

Optimum values observed for fresh rhizome.

- Optimum values observed for fresh rhizome and leaves. 
Table 11: GC - MS analysis of ginger oil

\begin{tabular}{ll}
\hline Compound & Content $^{\#}$ \\
Alpha-pinene & 0.96 \\
Camphene & 0.84 \\
Beta-myrcene & 0.06 \\
Santo linatriene & 0.01 \\
Limonene & 2.3 \\
Sabinene & 0.50 \\
Beta-phellandrene & 1.02 \\
1,8 cineole & 0.87 \\
Linalool & 1.09 \\
Borneol & 0.9 \\
Alpha-terpineol & 1.2 \\
Neral & 3.5 \\
Geranial & 7.3 \\
Copaene & 1.7 \\
Beta-elemene & 1.5 \\
Alpha-farnesene & 1.2 \\
Beta-farnesene & 2.0 \\
Beta-sesquiphellandrene & 3.5 \\
Ar-curcumene & 4.0 \\
Zingiberene & 20.0 \\
Beta-bisabolene & 5.5 \\
Trans beta-bisabolene & 3.5 \\
Cis-nerolidol & 2.0 \\
Alpha-eudesmol & 0.36 \\
Cedrenol & 0.6 \\
Cis farnesol & 0.7 \\
\hline
\end{tabular}

\# denoted the composition \% of ginger oil.

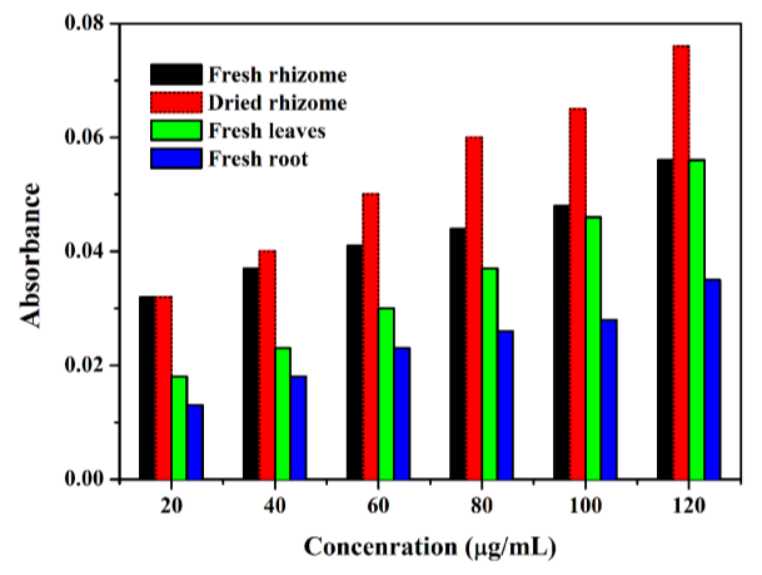

Graph 1: TRP assay of ginger

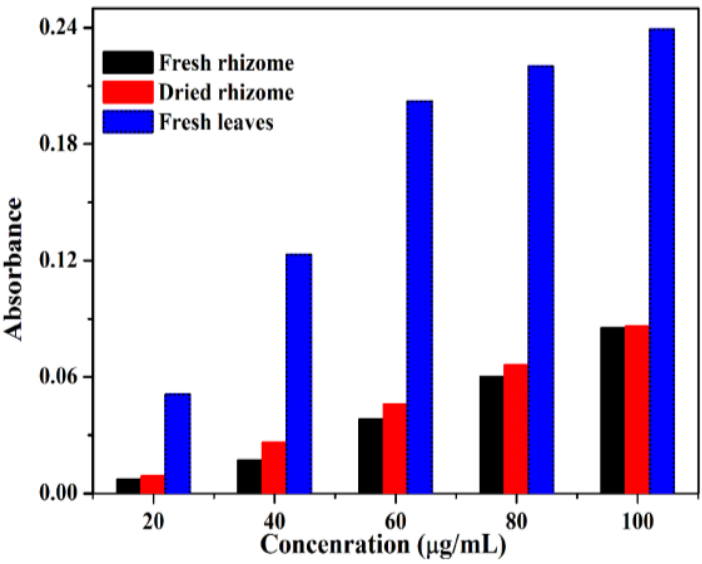

Graph 2: TRP assay of turmeric 


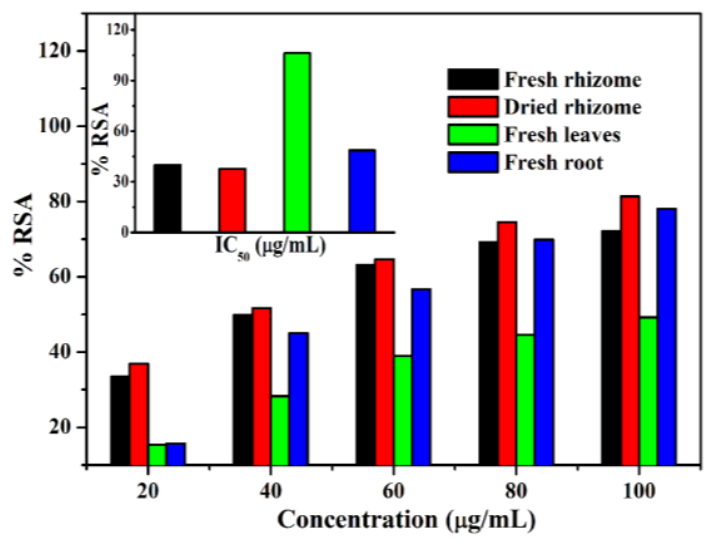

Graph 3: DPPH radical scavenging activity of ginger

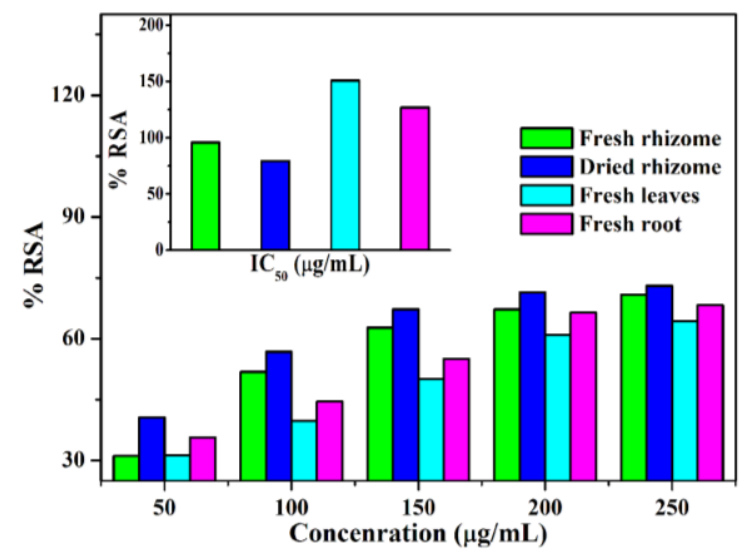

Graph 5: ABTS radical scavenging activity of ginger

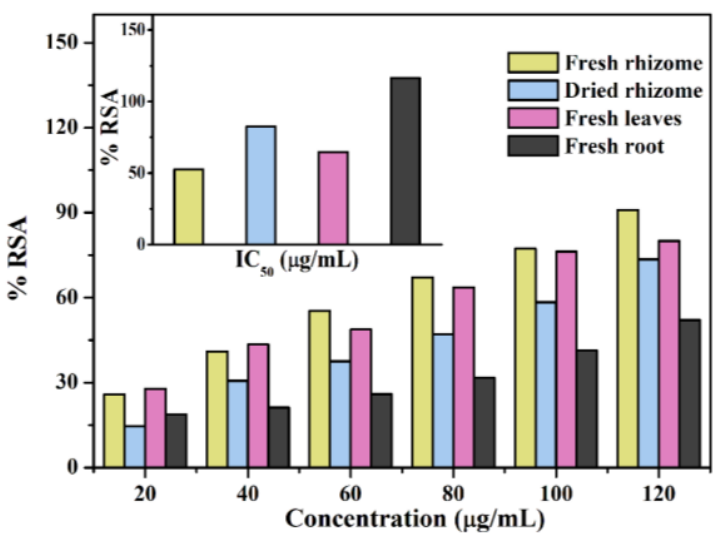

Graph 7: Superoxide radical scavenging activity of ginger

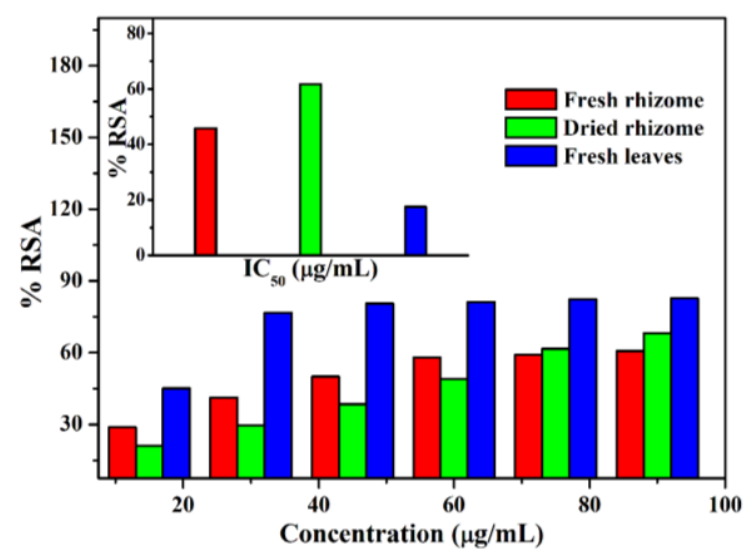

Graph 4: DPPH radical scavenging activity of turmeric

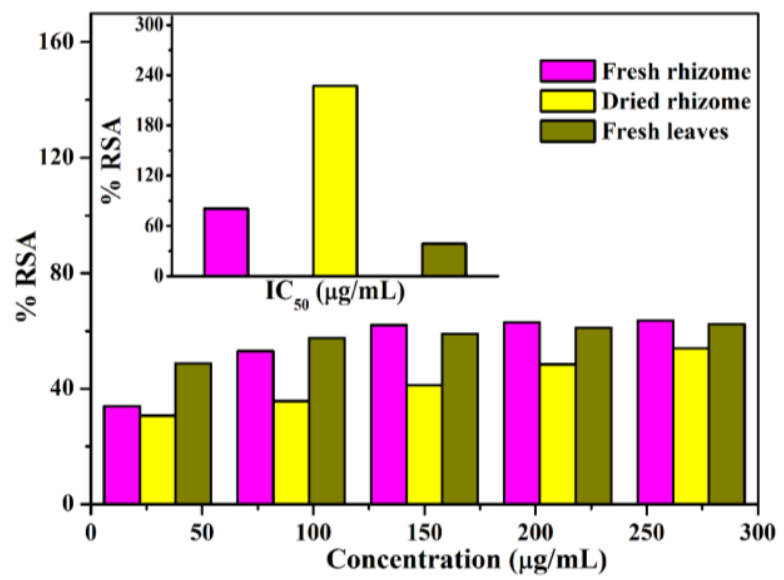

Graph 6: ABTS radical cation decolourization assay of turmeric

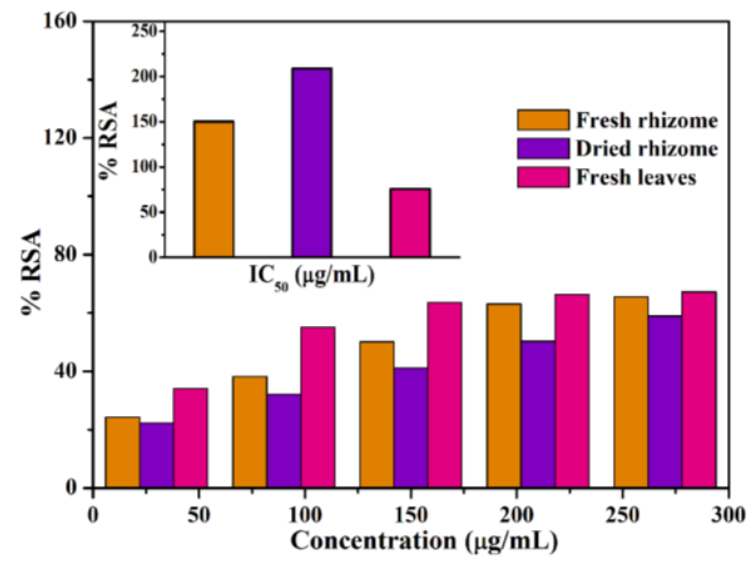

Graph 8: Superoxide radical scavenging activity of turmeric 


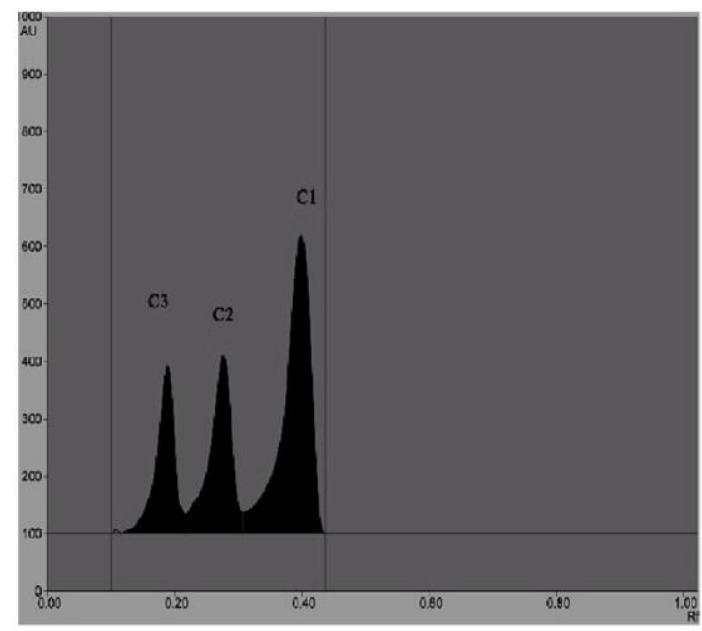

Graph 9: HPTLC chromatogram of curcuminoids in turmeric sample

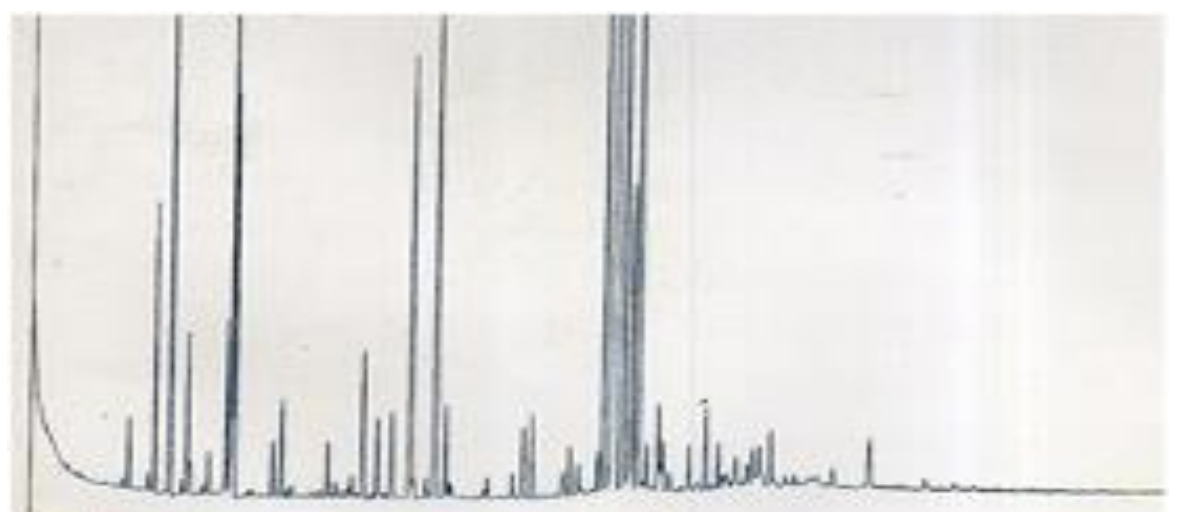

Figure 1: GC - MS analysis of volatile essential oil

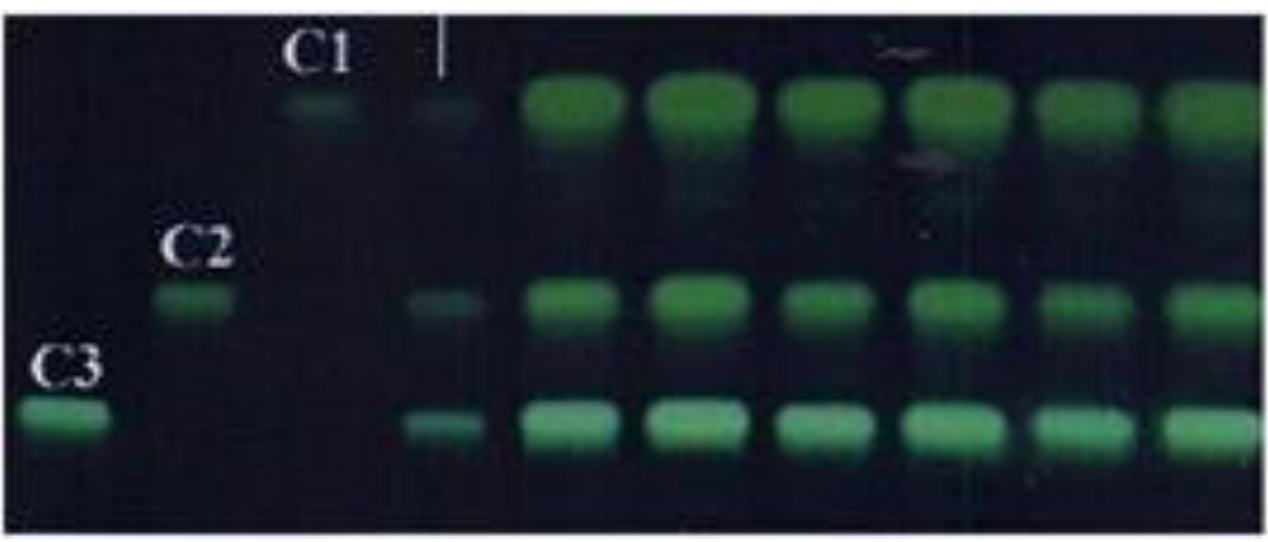

Figure 2: HPTLC chromatogram of turmeric sample

\section{Conclusion}

The effect of drying caused the terrific irreversible loss of antiradical property in turmeric which depended on the temperature and length of the processes. The highest percentages of antiradical activity and total phenolic content preservations were observed in fresh turmeric and dry ginger. 
The drying operation did not influence any noticeable effect in ginger except superoxide radical scavenging property. Hereafter the post harvesting agricultural wastes will be managed in better way for extraction and elucidation of active ingredients zingiberene and curcumin and these can knock out many of the existing harmful antiradicals and synthetic preservatives from food industries.

\section{Declaration of Interest}

The authors report no declarations of interest.

\section{Acknowledgements}

We really thank the Manonmaniam Sundaranar University, Tirunelveli and Mohamed Sathak engineering college, Kilakarai who were granted an end-to-end Service. This work was supported by the Department of science and technology DST - Science and engineering research board. (SERB), New Delhi, Government of India under Grant number Ref. No.: SR/FT/CS117/2011 dated 29.06.2012.

\section{References}

[1] Jovanovic, S.V.; Simic, M.G. Antioxidants in nutrition. Ann. N. Y. Acad. Sci. 2000, 899, 326334.

[2] Stanner, S.A.; Hughes, J.; Kelly, C.N.M.; Buttriss, J. A Review of the epidemiological evidence for the antioxidant hypothesis. Public Health Nutr. 2004, 7, 407-422.

[3] Sasikumar, B. Turmeric. In Handbook of Herbs and Spices; Peter, K. V., Eds.; Woodhead Publishing: Cambridge, 2012; 526-546.

[4] Cai, Y.; Luo, Q.; Sun, M.; Corke, H. Antioxidant activity and phenolic compounds of 112 traditional Chinese medicinal plants associated with anticancer. Life Sci. 2004, 74, 2157-2184.

[5] Chanda, S.; Dave, R. In vitro models for antioxidant activity evaluation and some medicinal plants possessing antioxidant properties: An Overview. Afr. J. Microbiol. Res. 2009, 3, 981-996.

[6] Chen, I.N.; Chang, C.C.; Ng, C.C.; Wang, C.Y.; Shyu, Y.T.; Chang, T.L. Antioxidant and antimicrobial activity of Zingiberaceae plants in Taiwan. Plant Foods Hum Nutr. 2008, 63, 1520.

[7] Verghese, J. Curcuminoids, the magic dye of C. longa L. rhizome. Indian Spices. 1999, 36, 1926.

[8] Hossain, M.; Brunton, N.; Barry-Ryan, C.; Martin-Diana, A.B.; Wilkinson, M. Antioxidant activity of spice extracts and phenolics in comparison to synthetic antioxidants. Rasayan J. Chem. 2008, 1,751-756.

[9] Prencipe, F.P.; Bruni, R.; Guerrini, A.; Rossi, D.; Benvenuti, S.; Pellati, F. Metabolite profiling of polyphenols in Vaccinium berries and determination of their chemopreventive properties. $\mathrm{J}$ Pharm Biomed Anal. 2014, 89, 257-267.

[10] Kocaadam, B.; Sanlier, N. Curcumin, an active component of Turmeric (Curcuma longa), and its effects on health. Crit Rev Food Sci Nutr. 2015, 0, 0-0. [in press].

[11] Gumusay, O.A.; Borazan, A.A.; Ercal, N.; Demirkol, O. Drying effects on the antioxidant properties of tomatoes and ginger. Food Chem. 2015, 173, 156-162.

[12] de Abreu, W.C.; Barcelos, M.D.F.P.; de Barros Vilas Boas, E.V.; da Silva, E.P. Total Antioxidant Activity of Dried Tomatoes Marketed in Brazil. Int J Food Prop. 2014, 17, 639-649.

[13] Yu, Z.F.; Kong, L.D.; Chen, Y. Antidepressant activity of aqueous extracts of Curcuma longa in mice. J Ethnopharmacol. 2002, 83, 161-165. 
[14] Singleton, V.L.; Rossi, J.A. Colorimetry of total phenolics with phosphomolybdicphosphotungstic acid reagents. Am J Enol Vitic, 1965, 16, 144-158.

[15] Stratil, P.; Klejdus, B.: Kubanhacek, V. Determination of total content of phenolic compounds and their antioxidant activity in vegetables-Evaluation of spectrophotometric methods. J. Agric. Food Chem. 2006, 54, 607-616.

[16] Pulido, R.; Bravo, L.; Saura-Calixto, F. Antioxidant activity of dietary polyphenols as determined by a modified ferric reducing/antioxidant power assay. J. Agric. Food Chem. 2000, 48, 33963402 .

[17] Saito, S.; Kawabata, J. Effects of electron-withdrawing substituent on DPPH radical Scavenging reactions of protocatechuic acid and its analogues in alcoholic solvents. Tetrahedron. 2005, 61, 8101-8108.

[18] Cotelle, N.; Bernier, J.L.; Catteau, J.P.; Pommery, J.; Wallet, J.C.; Gaydou, E.M. Antioxidant properties of hydroxy-flavones. Free Radic. Biol. Med. 1996, 20, 35-43.

[19] Re, R.; Pellegrini, N.; Proteggente, A.; Pannala, A.; Yang, M.; Rice-Evans, C. Antioxidant activity applying an improved ABTS radical cation decolorization assay. Free Radic. Biol. Med. 1999, 26, 1231-1237.

[20] Karlsson, J. Exercise, muscle metabolism and the antioxidant defense. World Rev Nutr Diet. 1997, 82, 81-100.

[21] Huie, R.E.; Padmaja, S. The reaction of no with superoxide. Free Radic Res Commun. 1993, 18, 195-199.

[22] Koleva, I.I.; Van Beek, T.A.; Linssen, J.P.H.; De Groot, A.; Evstatieva, L.N. Screening the plant extracts for antioxidant activity: a comparative study on three testing methods. Phytochem. Anal. $2002,13,8-17$.

[23] Jiang, H.; Somogyi, A.; Timmermann, B.N.; Gang, D.R. Instrument dependence of electrospray ionization and tandem mass spectrometric fragmentation of the gingerols. Rapid Commun Mass Spectrom. 2006, 20, 3089-3100.

[24] Kahkonen, M.P.; Hopia, A.I.; Vuorela, H.J.; Rauha, J.P.; Pihlaja, K.; Kujala, T.S.; Heinonen, M. Antioxidant activity of plant extracts containing phenolic compounds. J. Agric. Food Chem. 1999, 47, 3954-3962.

[25] Jiang, H.; Somogyi, A.; Jacobsen, N.E.; Timmermann, B.N.; Gang, D.R. Analysis of curcuminoids by positive and negative electrospray ionization and tandem mass spectrometry. Rapid Commun Mass Spectrom. 2006, 20, 1001-1012.

[26] Jiang, H.; Timmermann, B.N.; Gang, D.R. Use of liquid chromatography - electrospray ionization tandem mass spectrometry to identify diarylheptanoids in turmeric (Curcuma longa L.) rhizome. J Chromatogr A. 2006, 1111, 21-31.

[27] Jiang, H.; Solyom, A.M.; Timmermann, B.N.; Gang, D.R. Characterization of gingerol-related compounds in ginger rhizome (Zingiber officinale Rosc.) by High Performance liquid chromatography/electrospray ionization mass spectrometry. Rapid Commun Mass Spectrom. 2005, 19, 2957-2964.

[28] Xie, Z.; Ma, X.; Gang, D.R. Modules of co-regulated metabolites in turmeric (Curcuma longa) rhizome suggest the existence of biosynthetic modules in plant specialized metabolism, J. Exp. Bot. 2009, 60, 87-97.

[29] Shahidi, F.; Janitha, P.K.; Wanasundara, P.D. Phenolic antioxidants. Crit Rev Food Sci Nutr. 1992, 32, 67-103.

[30] Prieto, P.; Pineda, M.; Aguilar, M. Spectrophotometric quantitation of antioxidant capacity through the formation of a phosphomolybdenum complex: Specific application to the determination of vitamin E. Anal Biochem. 1999, 269, 337-341.

[31] Dehghannya, J.; Gorbani, R.; Ghanbarzadeh, B. Shrinkage of Mirabelle Plum during Hot Air Drying as Influenced by Ultrasound-Assisted Osmotic Dehydration. Int J Food Prop. 2016, 19, 1093-1103. 
[32] Kapoor, S.; Aggarwal, P. Drying Method Affects Bioactive Compounds and Antioxidant Activity of Carrot. Int. J. Veg. Sci. 2015, 21, 467-481.

[33] Chong, C. H.; Law, C. L.; Figiel, A.; Wojdylo, A.; Oziemblowski, M. Colour, phenolic content and antioxidant capacity of some fruits dehydrated by a combination of different methods. Food Chem. 2013, 141, 3889-3896.

[34] Kamiloglu, S.; Capanoglu, E. Polyphenol Content in Figs (Ficus carica L.): Effect of Sun-Drying. Int J Food Prop. 2015, 18, 521-535.

[35] Yeap, Y.S.Y.; Kassim, N.K.; Ng, R.C.; Ee, G.C.L.; Saiful Yazan, L.; Musa, K.H. Antioxidant properties of ginger (Kaempferia angustifolia Rosc.) and its chemical markers. Int J Food Prop. 2017, 0, 1-15 (in press).

[36] Lee, S.K.; Mbwambo, Z.H.; Chung, H.; Luyengi, L.; Gamez, E.J.; Mehta, R.G.; Kinghorn, A.D.; Pezzuto, J.M. Evaluation of the antioxidant potential of natural products. Comb Chem High Throughput Screen. 1998, 1, 35-46.

[37] Bayr, H. Reactive oxygen species. Crit. Care Med. 2005, 33, S498-S501.

[38] Sanchez-Moreno, C.; Larrauri, J.A.; Saura-Calixto, F. A procedure to measure the antiradical efficiency of polyphenols. J. Sci. Food Agric. 1998, 76, 270-276.

[39] Aruoma, O.I.; Murcia, A.; Butler, J.; Halliwell, B. Evaluation of the antioxidant and prooxidant actions of gallic acid and its derivatives. J. Agric. Food Chem. 1993, 41, 1880-1885.

[40] Branen, A.L. Toxicology and biochemistry of butylated hydroxyanisole and butylated hydroxytoluene. J Am Oil Chem Soc. 1975, 52, 59-63.

[41] Shao, H.B.; Chu, L.Y.; Lu, Z.H.; Kang, C.M. Primary antioxidant free radical scavenging redox signaling pathways in higher plant cells. Int J Biol Sci. 2008, 4, 8-14.

[42] Vashisth, T.; Singh, R.K.; Pegg R.B. Effects of drying on the phenolic content and antioxidant activity of muscadine pomace. LWT - Food Sci Technol. 2011, 44, 1649-1657.

[43] Methakhup, S.; Chiewchan, N.; Devahastin, S. Effects of drying methods and conditions on drying kinetics and quality of Indian gooseberry flake. LWT - Food Sci Technol. 2005, 38, 579587.

[44] Osman, A.M.; Wong, K.K.Y.; Fernyhough, A. The laccase/ABTS system oxidizes (+)-catechin to oligomeric products. Enzyme Microb Technol. 2007, 40, 1272-1279.

[45] Blois, M.S. Antioxidants determination by the use of a stable free radical. Nature. 1958, 181, 1199-1200.

[46] Maxwell, S.R.J. Prospects for the use of antioxidant therapies. Drugs. 1995, 49, 345-361.

[47] Li, J.; Wang, Y.; Ma, H.; Hao, J.; Yang, H. Comparison of chemical components between dry and fresh Zingiber officinale. Zhongguo Zhong Yao Za Zhi. 2001, 26, 748-751.

[48] Ramirez-Ahumada, M.D.C.; Timmermann, B.N.; Gang, D.R. Biosynthesis of curcuminoids and gingerols in Turmeric (Curcuma longa) and Ginger (Zingiber officinale): Identification of curcuminoid synthase and hydroxycinnamoyl-CoA thioesterases. Phyto chemistry. 2006, 67, 2017-2029.

[49] Demarchi, S.M.; Quintero Ruiz, N.A.; Concellon, A.; Giner, S.A. Effect of temperature on hot-air drying rate and on retention of antioxidant capacity in apple leathers. Food Bioprod Process. 2013, 91, 310-318.

[50] Miranda, M.; Maureira, H.; Rodriguez, K. Vega-Galvez, A. Influence of temperature on the drying kinetics, physicochemical properties and antioxidant capacity of Aloe Vera (Aloe Barbadensis Miller) gel. J. Food Eng. 2009, 91, 297-304.

[51] Kuljarachanan, T.; Devahastin, S.; Chiewchan, N. Evolution of antioxidant compounds in lime residues during drying. Food Chem. 2009, 113, 944-949.

[52] Katsube, T.; Tsurunaga, Y.; Sugiyama, M.; Furuno, T.; Yamasaki, Y. Effect of air-drying temperature on antioxidant capacity and stability of polyphenolic compounds in mulberry (Morus alba L.) leaves. Food Chem. 2009, 113, 964-969. 
[53] Poonam Khatri, J.S.; Rana Pragati Jamdagni.; Anil Sindhu. Phytochemical screening, GC-MS and FT-IR analysis of methanolic extract leaves of Elettaria cardamomum. International journal of research - Granthaalayah. 2017, 5, 213-224.

[54] Aziz, S.; Hassan, S.M.; Nandi, S.; Naher, S.; Roy, S.K.; Sarkar, R.P.; Hossain, H. Comparative studies on physicochemical properties and GC-MS analysis of essential oil of the two varieties of ginger (Zingiber officinale). Int. J. Pharm. Phytopharm. Res. 2017, 1, 367-370.

[55] Koch, W.; Kukula-Koch, W.; Marzec, Z.; Kasperek, E.; Wyszogrodzka-Koma, L.; Szwerc, W.; Asakawa, Y. Application of Chromatographic and Spectroscopic Methods towards the Quality Assessment of Ginger (Zingiber officinale) Rhizomes from Ecological Plantations. Int. J. Mol. Sci. 2017, 18, 452.

[56] Ahui, M.L.B.; Konan, A.B.; Zannou-Tchoko, V.J.; Amonkan, A.K.; KatiCoulibaly, S.; Offoumou, M.A. Identification of Gingerols in Ginger (Zingiber officinale Roscoe) by high performance liquid chromatography-tandem mass spectrometry and pharmacologic studies of its aqueous extract on the rabbit isolated duodenum contractility. J. Phys Pharm Adv. 2013, 3, 1626.

[57] Patel, K.; Krishna, G.; Sokoloski, E.; Ito, Y. Preparative separation of curcuminoids from crude curcumin and turmeric powder by $\mathrm{pH}$-zone-refining countercurrent chromatography. J. Liq. Chrom. \& Rel. Technol. 2000, 23, 2209-2218.

[58] Ali, I., Haque, A.; Saleem, K. Separation and identification of curcuminoids in turmeric powder by HPLC using phenyl column. Anal. Methods. 2014, 6, 2526-2536.

[59] Sahne, F; Mohammadi, M.; Najafpour, G.D.; Moghadamnia, A.A. Enzyme assisted ionic liquid extraction of bioactive compound from turmeric (Curcuma longa L.): Isolation, purification and analysis of curcumin. Ind Crops Prod. 2017, 95, 686-694.

[60] Lee, K.J.; Kim, Y.S.; Ma, J.Y. Separation and Identification of Curcuminoids from Asian turmeric (Curcuma longa L.) using RP-HPLC and LC-MS. Asian J. Chem. 2013, 25, 909-912.

[61] Xu, G.; Hao, C.; Tian, S.; Gao, F.; Sun, W.; Sun, R. A method for the preparation of curcumin by ultrasonic-assisted ammonium sulfate/ethanol aqueous two phase extraction. J. Chromatogr. B. 2017, 1041-1042, 167-174.

[62] Niamnuy, C.; Devahastin, S.; Soponronnarit, S. Some recent advances in micro Structural modification and monitoring of foods during drying: A review. J. Food Eng. 2014, 123, 148-156. 